\title{
PROBLEMA MANAJEMEN BIROKRASI PROYEK PEMBANGUNAN DALAM PENGEMBANGAN PARTISIPASI MASYARAKAT
}

\author{
David Widihandojo \\ Fakultas Bisnis Universitas Kristen Duta Wacana
}

\begin{abstract}
ABSTRAK
Salah satu tujuan yang ingin dicapai melalui program dan proyek-proyek pembangunan pemerintah adalah tumbuhnya partisipasi aktif masyarakat dalam proses perencanaan dan penerapan proyek-proyek pembangunan. Gagasan ini didasarkan pada konsep bahwa melalui proses partisipasi, masyarakat akan memahami nilai, tujuan dan manfaat proyek-proyek pembangunan tersebut bagi dirinya sehingga pada saat proyek diterapkan akan mentransformasi kehidupan masyarakat menuju kesebuah kehidupan yang lebih maju dan mapan. Dengan demikian, proyek pembangunan tersebut memberikan dampak yang signifikan bagi kemajuan masyarakat tersebut. Namun realitas di lapangan jauh berbeda masyarakat cenderung pasif dan tidak terlibat dalam proyek pembangunan. Pada umumnya para perencana dan pelaksana pembangunan melihat bahwa penyebab dari kepasifan ini terletak di dalam masyarakat itu sendiri yaitu pada nilai, budaya, tingkat pendidikan. Terkait dengan masalah kepasifan masyarakat ini, Penulis mengajukan argumen bahwa tatanan manajemen birokrasi proyek pembangunan itu sendiri adalah salah satu penghambat per- tumbuhan partisipasi masyarakat. Sistem pengawasan yang ketat, keterikatan irama kerja pada periode anggaran serta kontradiksi-kontradiksi dalam proses pengambilan keputusan antara pucuk pimpinan dengan para pelaksana di lapangan. Seluruh faktor-faktor ini membuat birokrasi proyek pembangunan menjadi tidak sensitif pada pertumbuhan aspirasi masyarakat untuk berpartisipasi. Untuk mengatasi problema manajemen ini perlu dibangun sebuah mekanisme informasi di luar birokrasi dan dalam hal ini Model Tindak Manusia (Human Action Model) seperti yang telah diujicobakan oleh PSLH-ITB di Ciamis dapat dipertimbangkan sebagai alternatif untuk diterapkan dalam implementasi proyek-proyek pembangunan sehingga dapat menjembatani kelemahan manajemen birokrasi pembangunan tersebut.
\end{abstract}

\begin{abstract}
One of the objectives to be achieved through development programs and projects is the growth of community participation in the planning and the implementation process of development projects, which is based upon the ideas that through participation the communities would accept the ideals and understand the benefit of the project. Thus in turn, the project will be supported and transform the communities towards a more develop one. However, the reality is far different, people tend to be passive and not involved in the development process; hence, the development planners and managers see the cause of the passivity lies in the community itself, whether it's cultural values, education level, etc. The author argues one of the causes of the lack of participation of the community lies in the bureaucratic structure of the project management itself. Strict monitoring system, the attachment of working rhythms to the budget period of time and the existence of two levels of decision making between the chief executive and the project managers. These factors make the bureaucracy of the development project insensitive to the growing aspirations of the community to participate. In the closing part, the author proposes the Human Action Model as has been tested by PSLH-ITB in Ciamis as an alternative to be
\end{abstract}


JRMB, Volume 16, No. 1, Juni 2021

applied in the implementation of development projects to bridge the weaknesses of the development project management.

\section{PENDAHULUAN}

Salah satu masalah utama yang dihadapi pemerintah kita dan juga banyak pemerintahan di negara-negara sedang berkembang adalah banyaknya proyekproyek pembangunan yang hasil akhirnya melenceng jauh dari tujuan dan sasaran yang disepakati sebelumnya. Masalah ini tidaklah hanya sekedar salah urus belaka dimana solusinya adalah mengirim pengelola proyek ke kursus-kursus manajemen. Namun permasalahannya jauh lebih dalam lagi yaitu karena partisipasi masyarakat yang diharapkan muncul melalui proyek-proyek pembangunan ini ternyata tidak terjadi. Jika saja masyarakat ikut terlibat dalam melakukan pengawasan maka kemungkinan besar tujuan dan sasaran proyek akan tercapai.

Selama ini apa yang diartikan partisipasi adalah mobilisasi masyarakat yaitu ramai-ramai membersihkan selokan \& jalanan, ramai-ramai menghias pot bunga di pinggir jalanan ataupun ramairamai hadir di lapangan desa mendengarkan ceramah bapak-bapak dan ibu-ibu yang terhormat dari Jakarta belaka. Akibatnya, partisipasi yang diartikan sebagai keterlibatan aktf masyarakat dalam proses perencanaan, pelaksanaan dan pengawasan proyek-proyek pembangunan tidak pernah terjadi.

Pemerintah sendiri sangat mengharapkan munculnya partisipasi masyarakat dan ini nampak jelas dalam berbagai kebijakan pembangunan yang ada. Sekalipun seperti yang dikemukakan oleh Enny Karnawati (2014) bahwa tingkat partisipasi masyarakat yang terjadi tidaklah seperti yang diharapkan. Namun paling tidak pemerintah telah merumuskan munculnya partisipasi masyarakat dalam empat bentuk yaitu:

Partisipasi dalam Pengambilan Keputusan: Partisipasi masyarakat dalam pembangunan di wilayahnya perlu ditumbuhkan melalui forum yang memungkinkan masyarakat berpartisipasi langsung dalam proses pengambilan keputusan dalam menetapkan program pembangunan di wilayah setempat.

1. Partisipasi dalam Pelaksanaan Pembangunan: Dalam pelaksanaan kegiatan pembangunan, perlu adanya pemerataan sumbangan masyarakat dalam bentuk tenaga kerja, uang tunai, dan atau bentuk lainnya yang sepadan dengan manfaat yang akan diterima oleh warga masyarakat.

2. Partisipasi dalam Pemantauan dan Evaluasi Pembangunan: Bentuk partisipasi masyarakat dalam memantau dan mengevaluasi program dan kegiatan pembangunan sangat diperlukan, guna mengetahui apakah tujuan yang dicapai sudah sesuai dengan harapan. Selain itu juga untuk memperoleh umpan balik tentang masalah/kendala yang muncul dalam pelaksanaan pembangunan yang sedang dilaksanakan.

3. Partisipasi dalam Pemanfaatan Hasil Pembangunan: Seringkali masyarakat tidak memahami manfaat dari program pembangunan sehingga hasil pembangunan menjadi sia-sia. Dengan demikian, perlu adanya partisipasi masyarakat untuk memanfaatkan hasil pembangunan, misalnya: memanfaatkan jembatan penyeberangan jalan.

\section{KERANGKA STUDI}

Studi ini didasarkan pada observasi lapangan Penulis pada saat terlibat dalam berbagai proyek pengembangan masyarakat dan peningkatan kesadaran hukum yang dijalankan oleh YBKS, sebuah LSM di Solo, Jawa Tengah serta berbagai daerah lainnya di luar Jawa karena YBKS memiliki jaringan kerja yang luas secara nasional. Dalam menjalankan proyek-proyeknya kami, para 
staff dan aktivis YBKS, seringkali bertemu dengan para pelaksana proyek-proyek pembangunan pemerintah. Dalam pertemuan tersebut selalu terjadi diskusi dan tukar menukar pendapat untuk mendiskusikan berbagai gagasan ataupun masalah dalam implementasi proyekproyek pembangunan pemerintah. Para pelaksana lapangan LSM selalu memiliki sudut pandang yang sangat berbeda dengan para pelaksana lapangan proyekproyek pembangunan pemerintah. Sekalipun demikian seluruh perjumpaan dan percakapan ini menjadi masukan yang sangat berarti dan memperluas wawasan Penulis dalam memahami proses pembangunan yang tengah berlangsung ditengah bangsa ini.

Seluruh pengalaman dan percakapan tersebut direkam oleh penulis dan menjadi masukan untuk penulisan ini. Selanjutnya Penulis melakukan studi kepustakaan yang mendalam untuk memahami berbagai teori serta menggali berbagai studi kasus pengembangan partisipasi masyarakat dari berbagai daerah di Indonesia, di Asia, Amerika Latin dan Afrika untuk lebih mematangkan konteks permasalahan serta menemukan benang merah yang ada. Dalam proses menggali berbagi studi kasus di lapangan, Penulis menemui bahwa para pakar telah membuktikan partisipasi masyarakat tidaklah dapat begitu saja ditumbuhkan oleh intervensi pemerintah melalui implementasi proyekproyek pembangunan. Banyak sekali hambatan yang muncul baik dari dalam masyarakat sendiri maupun dari dalam birokrasi pemerintah. Faktor-faktor seperti sistem perekonomian, tatanan struktur masyarakat, tingkat pendidikan, kesadaran politik, konflik kepentingan antar kelompok dan bentuk negara, semuanya ikut mempengaruhi tingkat partisipasi masyarakat (Atal \& Pieris, 1980; Berger, 1982; Budiman, 1982 \& 1987; Chambers, 1983; Hadad, 1983; Hettne, 1986; Kusumowidagdo, 1983; Robison, 1985; Roxborough, 1986; Scott,
1981; Sibero, 1986 dan Soetrisno, 1985).

Selain itu Penulis juga menggali kerangka teoritik yang dikembangkan baik oleh para pakar maupun tenaga ahli dari World Bank/IMF dan lembaga-lembaga donor global yang banyak berkecimpung di negara-negara sedang berkembang. Seluruh proses ini untuk mematangkan gagasan- gagasan yang muncul dalam pengalaman lapangan tersebut untuk diangkat kesebuah tulisan yang memenuhi standar bagi sebuah diskusi akademik.

Dalam studi ini penulis tidak menguji cobakan teori-teori dilapangan tetapi lebih pada upaya mengangkat hasil observasi dari pengalaman langsung dilapangan ketataran teoritik dengan menerapkan pendekatan induktif (inductive reasoning) yang dipahami sebagai berikut:

"Inductive reasoning is a method of reasoning in which the premises are viewed as supplying some evidence, but not full assurance, of the truth of the conclusion. It is also described as a method where one's experiences and observations, including what are learned from others, are synthesized to come up with a general truth. Many dictionaries define inductive reasoning as the derivation of general principles from specific observations (arguing from specific to general)." (Rainbolt,et.al, 2014, hal. 57. Lihat juga. "Deductive and Inductive Arguments," Stanford Encyclopedia of Philosophy)

Khusus bagi tulisan ini, penulis fokus pada problema manajemen birokrasi dalam proyek-proyek pembangunan pemerintah yang ditengarai menghambat tumbuhnya partisipasi masyarakat. Ada cukup banyak problema manajemen birokrasi yang terjadi namun untuk tulisan ini 
Penulis membatasi diri hanya membahas dua permasalahan yang mendasar terjadi pada manajemen birokrasi proyekproyek pembangunan pemerintah yaitu keterikatan waktu kerja dan periode peranggaran dan adanya dua aras pengambilan keputusan

\section{Problema Manajemen Birokrasi Proyek Pembangunan}

Pada umumnya pemerintah melihat birokrasi proyek pembangunan dalam kaca mata Weberian, bahwa birokrasi itu adalah alat yang netral. Birokrasi itu terdiri dari pelaksana-pelaksana yang efektif dan efisien sehingga tidak perlu dipersoalkan lagi. Selain itu juga diyakini bahwa peraturan-peraturan, kontrol hierarkis yang ketat, serta sistem promosi yang tergantung pada ketrampilan administratif dalam menyelesaikan persoalan akan membentuk sebuah birokrasi yang efektif dan efisien (Weber, 1922; Serpa \& Ferreira, 2019). Weber mengemukakan birokrasi tumbuh dan berkembang dalam sebuah proses, yang dia sebut sebagai 'rationalisation of society' (Pollitt, 2008). Proses inilah yang menyebabkan, apa yang disebut 'a growing impersonality in the social relationship' (Aron, 1994; Giddens, 1997).

Dalam kacamata Weber hadirnya birokrasi dalam sebuah negara modern mengukuhkan ter - bentuknya sebuah masyarakat yang rasional. Birokrasi negara mendorong modernisasi masyarakat melalui penerapan prinsipprinsip umum yang rasional dalam mengatasi berbagai permasalahan yang terjadi dan ini meningkatkan kemampuan masyarakat untuk mengatasi lingkungan yang labil dan dalam mengelola kompleksitas masyarakat. Oleh karena tindakan yang didasarkan pada perhitungan ataupun asumsi-asumsi yang rasional akan mengurangi ketidakpastian yang terjadi dalam kehidupan sehari-hari. (Touraine, 1988; Clegg, 1990). Dengan demikian birokrasi adalah sistem yang rasional - dalam kacamata para pejabat pemerintah - jika terjadi permasalahan dalam pelaksanaan proyek-proyek pembangunan. Akar masalahnya tidak terletak didalam tatanan birokrasi tersebut tetapi terletak pada cakap atau tidaknya para manajer proyek yang diukur dari capaian kinerja.

Dengan demikian, berbagai bentuk relasi yang terjadi baik didalam birokrasi ataupun antara birokrasi dengan berbagai pihak diluar birokrasi tidak perlu dipersoalkan lagi (Van Ufford, 1987). Kajianpun lebih difokuskan pada keputusan-keputusan yang akan diambil dan dampak dari keputusan- keputusan tersebut. Akibatnya, kajian tidak difokuskan pada proses pengambilan keputusan dan relasi yang terjadi antar kelompok maupun individu yang terlibat dalam perencanaan serta penerapan proyek itu sendiri. Kurang perhatiannya pada proses pengambilan keputusan dan relasi antar kelompok ini mendorong munculnya masalah yang disebut oleh Offenbacker (2004) sebagai "over-bureaucratized" seperti yang ditulisnya bahwa, "people lose interest because the processes become over-bureaucratized." Berdasarkan pengamatan penulis dilapangan overbureaucratized muncul dalam dua bentuk permasalahan dalam manajemen birokrasi proyek-proyek pembangunan pemerintah yang terkait langsung dan menjadi hambatan utama bagi tumbuh dan berkembangnya partisipasi masyarakat yaitu;

Pertama. Ketatnya Keterikatan Irama Kerja Proyek Dengan Periode Anggaran. Salah satu hambatan yang muncul dari dalam birokrasi adalah ketatnya keterikatan irama waktu kerja dan periode anggaran (Poerbo \& Nordholt, 1983). Untuk mendapatkan gambaran atas masalah ini marilah kita kaji pengalaman Paulus Hidayat Santosa di lapangan dengan proyek-proyek kesehatan pemerintah,

"Inisiatif yang muncul dari masyarakat daerah dalam membuat program terhambat. Oleh karena kinerja 
para manajer proyek dievaluasi berdasarkan keberhasilan menjalankan kegiatan yang sudah terencana dan bukannya pada keberhasilan meningkatkan partisipasi masyarakat dalam meningkatkan kesehatan penduduk setempat....

Sedangkan sistem anggaran menciptakan lebih banyak kekakuan karena anggaran sangat rinci dan wajib dipatuhi secara ketat..."

"Program harus dilaksanakan sesuai dengan anggaran tidak peduli apakah program tersebut cocok atau tidak. Akibatnya sangat kecil kemungkinan untuk membuat program yang cocok dengan kondisi setempat. Kekakuan semacam ini menyebabkan sikap pasif para manajer... "Walaupun demikian para manajer merasa enak dan aman dengan sistem ini. Oleh karena memberikan pedoman yang jelas dan kepastian atas apa yang diharapkan dari mereka serta jaminan tersedianya dana. Para manajer tahu dengan pasti bahwa mereka dianggap berhasil jika menyelesaikan sederet kegiatan, bukannya mengubah keadaan kesehatan melalui partisipasi penduduk." (Santosa, Paulus Hidayat dikutip dari Budiman \& Van Ufford, 1988, hal 348363).

Apa yang ditulis Paulus Hidayat Santosa diatas ini berdasarkan pengalaman dan pengamatannya di lapangan dengan proyek-proyek pengembangan kesehatan masyarakat. Santosa menunjukkan dengan jelas bahwa sistem pengawasan aras atas birokrasi yang ketat menciptakan hambatan pada para pengelola di lapangan untuk bersikap tanggap terhadap kebutuhan di lingkungannya sehingga membatasi kreativitasnya dalam menyusun program-program yang mendorong tumbuh dan berkembangnya partisipasi publik dilingkungannya. Tumbuh dan berkembangnya partisipasi masyarakat membutuhkan waktu dan kebebasan manajer lapangan untuk melakukan kontak dengan masyarakat dan mengembang kan berbagai program untuk merespons kebutuhan masyarakat.

Hal yang sama terjadi di Thailand, Chakrit Noranitipadungkarn (1981) dan Damrong Thadee (1988) mengemukakan bahwa para manajer birokrasi pemerintah Thailand sangat dibatasi kemampuannya untuk mengembangkan partisipasi masyarakat dalam proyek-proyek pembangunan oleh kebijakan- kebijakan manajemen aras atas birokrasi dan salah satu diantaranya adalah pengawasan hirarkis yang ketat dalam bentuk peraturan-peraturan pengawasan yang spesifik dan ketat. Namun semua ini pada ujungnya hanya menumbuhkan perilaku mengambil muka atasan yang meluas.

Di Indonesia hal yang sama yang terjadi, Poerbo (1982) mengemukakan bahwa sikap ABS (Asal Bapak Senang) sangat kuat mewarnai perilaku para manajer lapangan. Sikap ini sangat bertentangan dengan upaya pemerintah untuk mencapai keterpaduan antara pendekatan top-down dengan bottom-up. Perilaku ABS hanyalah gejala penyelamatan diri (survival mechanism) yang umum terjadi dalam setiap organisasi hirarkis dimanapun di dunia ini. Hanya saja tingkat keparahannya sangat ditentukan oleh kondisi masyarakat dilingkungan organisasi tersebut. Khususnya di Indonesia, sikap ABS ini telah sedemikian parahnya sehingga menjadi keluhan yang meluas serta pembicaraan yang ramai di masyarakat. Salah satu penyebab dari memburuknya masalah ABS di Indonesia bukan karena ketatnya pengawasan dari atasan namun disebabkan oleh manajemen aras atas birokrasi yang mengubah mekanisme pengawasan menjadi instrumen yang mengalirkan kekayaan serta fasilitas dari aras bawah ke aras atas organisasi yang menyebabkan merosotnya kualitas penerapan proyek-proyek pembangunan.

Kedua. Dua Proses Pengambilan Keputusan. Masalah diatas makin diperparah karena adanya keadaan, yang 
dikatakan oleh Mintzberg (1970) sebagai terpisahnya aras atas birokrasi dengan para pengelola yang mengalokasikan dana serta mengatur kegiatan. Keterpisahan ini makin lama makin dalam karena masing-masing pihak memiliki otonomi yang makin luas. Ini berarti terbentuk dua proses pengambilan keputusan yang berbeda serta otonom dan hanya terintegrasi secara longgar.

Mereka yang berada diaras atas birokrasi perhatiannya lebih dipusatkan pada relasi-relasi yang vital atas kesinambungan arus dana. Jadi mereka lebih banyak berhubungan dengan lembaga-lembaga donor, baik pemerintah ataupun swasta diaras internasional. Mereka melihat pentingnya mengembang kan kerjasama-kerjasama internasional bagi pembangunan demi menjaga kesinambungan arus dana. Dengan demikian mereka harus mengerti preferensi politik dan prioritas yang berubah-ubah dari lembaga-lembaga donor internasional; atas dasar pengetahuan itu rencana proyek di lapangan disesuai - kan sedemikian rupa sehingga memungkinkan untuk mendapatkan dana.

Kondisi semacam ini digambarkan secara tajam oleh Tendler (1975) yang menganalisis relasi USAID dengan mitramitranya. Relasi USAID dengan mitramitranya dapatlah digambarkan dengan konsep pasar yaitu ada pihak yang sangat membutuhkan uang dan ada pihak yang memiliki uang. Walupun pihak yang memiliki uang didesak untuk harus mengeluarkan uang namun kelemahan ini tidak nampak dalam proses negosiasi yang terjadi sehingga dapat memaksakan berbagai persyaratan kepada pihak yang membutuhkan uang. Akibatnya seperti dikemukakan oleh Myrdall (1968) berdasarkan pengalaman India bahwa ideologi para perencana pembangunan di India sangat ditentukan oleh tekanan donor-donor internasional sedangkan proyek-proyek pembangunan di lapangan terus menerus disesuaikan sedemikian rupa dengan perubahan-perubahan gagasan lembaga donor supaya dapat didanai. Untuk dapat memahami masalah ini mari kita lihat pengalaman dua lembaga donor yang berpengaruh yaitu lembaga-lembaga donor Netherlands dan Kanada. Lavergne (1988) meneliti kebijakan-kebijakan CIDA terhadap mitra-mitranya di Dunia Ketiga. Selain itu Erath \& Kruijt (1988) meneliti kebijakan- kebijakan lembaga donor Belanda di Indonesia dan Peru. Sedangkan lembaga-lembaga donor yang diteliti adalah Cebemo, ICCO, NOVIB dan HIVOS.

Pendekatan lembaga donor Kanada sangat berbeda dengan pendekatan lembaga-lembaga donor Belanda. Lembaga-lembaga donor Belanda memiliki kebijakan bantuan yang jauh lebih intervensionis dengan Kanada. Kebijakan lembaga donor Kanada adalah tetap menghargai kedaulatan pihak penerima dana sehingga manajemen lembaga donor Kanada dapat menerima perubahan-perubahan dalam program dan anggaran yang terjadi dikemudian hari. Sebaliknya, lembaga-lembaga donor Belanda berupaya melakukan intervensi kedalam kebijakan internal mitramitranya, khususnya menyangkut manfaat bagi masyarakat miskin. Namun upaya ini hanya mengakibatkan adanya kepurapuraan para birokrat proyek akibat dari kelemahan mereka untuk melakukan pengawasan di lapangan.

Berdasarkan kedua pendekatan ini, baik Kanada maupun Belanda pada akhirnya kembali pada hal yang sama yaitu hanya berhasil melakukan intervensi diaras atas birokrasi dan tidak berhasil merubah warna birokrasi proyek-proyek pembangunan, khususnya di aras pengelola di lapangan dimana terjadi alokasi dana. Demikian juga halnya dengan tujuan, sasaran, prinsip-prinsip serta berbagai faktor kualitatif lainnya menjadi sangat kabur. Ini membuktikan bahwa terjadi 2 proses yang terpisah yaitu antara aras atas dengan aras bawah birokrasi yang terdiri dari para pengelola di 
lapangan, keduanya memiliki otonomi yang terpisah. Keterpisahan ini sangat tajam sehingga pertanyaan-pertanyaan yang mendasar atas bobot kualitatif proyek bagi para pengelola di lapangan cenderung kesulitan menjawab.

Akibatnya para pimpinan diaras atas dengan pengelola diaras bawah berada dalam suatu posisi yang khas yaitu mereka terus menerus berunding tentang dana dan pelaksanaan proyek. Pimpinan puncak berunding dengan lembaga donor; kemudian berunding dengan manajer menengah. Sedangkan manajer menengah berunding dengan para pengelola di lapangan. Begitulah terus menerus, makin panjang rantai birokrasi makin sering terjadi perundingan. Akibatnya proyek pembangunan menjadi rantai negosiasi yang terus menerus. Negosiasi tingkat internasional, dilanjutkan dengan tingkat nasional, tingkat propinsi hingga tingkat lokal demikian seterusnya. Artinya, proyek yang semula disepakati antara pimpinan manajemen aras atas dengan mitra kerja lembaga-lembaga donor global direkonstruksikan dalam perundingan, kemudian direkonstruksikan kembali berulang kali supaya dapat melewati rantai negosiasi. Makin panjang rantai birokrasi makin sering pula terjadi rekonstruksi proyek tersebut.

Lalu bagaimana kaitan antar negosiasi? Sampai seberapa besar terjadi perubahan gagasan dasar proyek? Sampai seberapa jauh gagasan kualitatif yang indah dari pimpinan proyek yang duduk di manajemen aras atas mempengaruhi para manajer proyek dilapangan? Agniezka \& Schemann (2001, hal.76) mengemukakan dalam proses semacam ini yaitu dimana proyek direkonstruksi berulang kali akan terjadi penggantian tujuan dan sasaran proyek (goal displacement). Ini terjadi karena adanya perumusan ulang tujuan, sasaran dan prioritas yang berbeda dengan tujuan, sasaran dan prioritas yang semula dirumuskan. Perumusan ulang in terjadi karena kondisi yang berbeda yang dihadapi oleh para manajer proyek, artinya, proses penetapan tujuan, sasaran dan prioritas proyek adalah sebuah proses yang dinamis, yang terus menerus berubah disepanjang rantai birokrasi.

Tujuan, sasaran dan prioritas dirumuskan ulang jika terjadi perubahan arus dana, personil dan adanya kepentingan-kepenting baru. Ini berarti tujuan utama yang merupakan identitas dari proyek hanya dapat mengarahkan pengambilan keputusan interal pada saat awal proyek dan hanya bertahan selama pimpinan aras atas birokrasi memiliki kemampuan pengawasan administrasi organisasinya. Kondisi makin diperparah oleh adanya jarak lokasi geografis antara pimpinan dan lokasi proyek dilaksanakan (Scott, 1972; Hyden, 2008). Oleh karena jauhnya jarak geografis ini maka keputusan-keputusan yang menyangkut teknis pelaksanaan proyek harus diambil dalam situasi yang sangat berbeda. Perbedaan ini terjadi karena adanya perubahan alokasi dana dan konfigurasi kekuasaan.

Para pengelola di lapangan cenderung untuk hanya memenuhi tujuan tertentu dengan didasarkan pada rasionalitas serta efisiensi yang situasional dengan keadaannya. Akibatnya para pengelola di lapangan cenderung memilih kelompok tertentu yang paling menjamin tercapainya tujuan yang telah ditetapkan sebelumnya (Effendy, 1989). Berdasarkan kasus di Bangladesh, Van Schendell (1981) menemukan bahwa kantor-kantor pemerintah didominasi oleh elit lokal setempat sedangkan kebijakan- kebijakan pusat dianggap sepi serta cenderung diubah. Sedangkan untuk kasus Indonesia, Sofian Effendi (1989) berdasarkan penelitiannya menemukan aparat birokrasi cenderung menghindari kelompok masyarakat miskin. Oleh karena melayani kelompok masyarakat ini membutuhkan waktu yang lebih lama dan meningkatkan resiko tidak tercapainya sasaran proyek. 
Salah satu yang diteliti Effendi adalah pemanfaatan Fasilitas Kesehatan Pemerintah, Puskesmas dan Rumah Sakit, oleh masyarakat yang diklasifikasikan sebagai Atas, Menengah dan Bawah berdasarkan penghasilan. Hasilnya mereka yang Melapor Sakit di dominasi oleh kelompok Atas 37\% sedangkan kelompok Menengah 29\% dan Bawah 34\%. Sedangkan Penggunaan Puskesmas di dominasi oleh kelompok Menengah 46\%, kelompok Atas 33\% dan Bawah 21\%. Demikian juga dengan Penggunaan Rumah Sakit di dominasi oleh kelompok Atas $62 \%$, sedangkan Menengah 22\% dan Bawah 16\%. Disini nampak jelas bahwa Pelayanan Kesehatan Pemerintah hanya cenderung dinikmati kelompok Menengah dan Atas.

Data diatas menunjuk dengan bahwa yang menikmati Layanan Kesehatan Pemerintah di dominasi oleh kelompok Menengah dan Atas daripada kelompok Bawah yang jauh lebih membutuhkan. Apa yang terjadi dengan Layanan Kesehatan Pemerintah ini hanyalah ujung dari gunung es karena terjadi juga pada berbagai proyek pembangunan yang ditujukan bagi kelompok Bawah. Akar dari masalah ini cukup kompleks namun apa yang pasti adalah pendekatan ke kelompok Bawah membutuhkan lebih banyak waktu dan strategi yang lebih kompleks. Hal ini tidak pernah dipertimbangkan secara serius pada kerangka waktu proyek. Akibatnya para pelaksana di lapangan cenderung mengambil langkah yang aman yaitu memilih segmen masyarakat yang responsif dan terbuka yaitu kelompok Menengah dan Atas yang jauh lebih mudah dijangkau sehingga kelompok Bawah yang sebenarnya menjadi sasaran utama proyekproyek pembangunan selalu tertinggal.

Kondisi manajemen birokrasi seperti ini mengakibatkan layanan publik pemerintah cenderung hanya melayani kelompok Menengah dan Atas. Kecenderungan ini makin didorong dengan desakan untuk memenuhi target yang ditetapkan sebelumnya oleh manajemen aras atas birokrasi secara mengikat. Ketatnya pengawasan birokrasi ini terjadi karena pimpinan membutuhkan jaminan bahwa tujuan-tujuan proyek tercapai. Dengan jaminan ini pimpinan dapat meyakinkan lembaga donor bahwa kesepakatan yang diambil telah berjalan dengan baik dengan demikian arus dana dapat terjamin karena adanya kepercayaan (trust) dari lembaga-lembaga donor. Atas dasar itu pimpinan birokrasi cenderung menyukai adanya pengawasan yang ketat dan cenderung dijabarkan secara kuantitatif serta dikaitkan secara erat pada periode anggaran. Demi kemudahan dalam pengawasan dan untuk menjaga tingkat kepercayaan lembaga-lembaga donor.

Seluruh tuntutan dan problema manajemen birokrasi ini berakibat pada tidak berkembangnya partisipasi masyarakat. Oleh karena partisipasi masyarakat hanya akan tumbuh dan berkembang dalam iklim yang mendukung dimana dibutuhkan fleksibilitas birokrasi untuk mengembangkan partisipasi masyarakat. Disinilah terjadi dilema yang pelik bagi manajemen birokrasi proyekproyek pembangunan pemerintah, disatu sisi pucuk pimpinan di aras atas membutuhkan pengawasan yang ketat untuk menjamin lancarnya aliran dana dari lembaga-lembaga donor. Sedangkan dipihak lain, pengawasan yang ketat tersebut menyebabkan kekakuan manajemen birokrasi sehingga mematikan ketanggapan terhadap perkembangan partisipasi masyarakat yang bertentangan dengan gagasan dasar dari proyek-proyek pembangunan itu sendiri. Jadi kekakuan birokrasi itu sendiri terbentuk dari adanya kebutuhan untuk menjamin amannya keuangan proyek-proyek pembangunan tersebut. Inilah kontradiksi yang melekat dalam tatanan manajemen birokrasi proyek-proyek pembangunan itu sendiri.

\section{Memperlancar Arus Informasi}

Salah satu upaya yang dapat dilakukan untuk mengatasi kekakuan manajemen birokrasi proyek- proyek 
pembangunan adalah dengan memperlancar arus informasi antara masyarakat yang menjadi sasaran proyek dengan para perencana dan manajer proyek-proyek pembangunan baik diaras bawah, menengah dan atas. Ini adalah sebuah upaya membangun mekanisme informasi dan pengawasan diluar struktur birokrasi yang ada. Mekanisme semacam ini makin dibutuhkan untuk menjamin keberhasilan proyek pembangunan. Oleh karena makin terpusatnya kekuasaan hanya pada para pimpinan manajemen aras atas serta para pengelola proyek. Sedangkan bagi masyarakat sendiri selain kurang memiliki informasi juga tidak terorganisasi sehingga manajemen proyek cenderung meninggalkan masyarakat dalam pelaksanaan proyek.

Masalah semacam ini timbul oleh karena para pimpinan manajemen aras atas dan para pengelola proyek dilapangan pada umumnya meyakini bahwa proyek yang dikelola tersebut telah sesuai dengan aspirasi dan kebutuhan masyarakat. Oleh karena seluruh proyek-proyek tersebut didasarkan pada sebuah penelitian terlebih dahulu. Problem dari penelitian deduktif yang dilakukan dalam proses persiapan bagi sebuah proyek pembangunan adalah para peneliti cenderung mengabaikan apa yang disebut oleh Berger (1982) sebagai Partisipasi Kognitif.

Dalam penelitian-penelitian sosial dengan pendekatan deduktif yang pada umumnya dijalankan dalam proses persiapan bagi sebuah proyek pembangunan. Para peneliti cenderung terjebak kedalam asumsi bahwa kaum terdidik jauh lebih tahu dan lebih memahami tolok ukur pembangunan. Dengan demikian seluruh perangkat penelitian ditetapkan terlebih dahulu, mulai dari jumlah responden, bentuk pertanyaan dan teknik analisis, semuanya ditetapkan terlebih dahulu secara lengkap sebelum bertemu dengan masyarakat. Ini berarti masyarakat sasaran sebagai responden telah dibatasi terlebih dahulu dalam mengungkapkan permasalahan. Masyarakat hanya diperbolehkan berbicara sesuai kebutuhan peneliti dan sesuai dengan daftar pertanyaan. Ini berarti, permasalahan masyarakat diartikan oleh para peneliti, bukan oleh masyarakat itu sendiri. Masyarakat dibatasi kebebasannya untuk mengungkapkan masalah kehidupannya sendiri sehingga dinamika kehidupan dan permasalahan masyarakat yang jauh lebih luas serta kompleks kemungkinan besar luput dari perhatian peneliti.

Pembangunan dengan berbagai program serta tujuan yang akan dicapai merupakan kegiatan eksternal bagi masyarakat sasaran. Pada umumnya masyarakat sasaran telah mapan sebagai sebuah komunitas; dengan demikian, program dan tujuan proyek-proyek pembangunan yang telah ditetapkan sebelumnya belum tentu sesuai dengan kebutuhan serta harapan masyarakat setempat. Akibatnya masyarakat memang belum siap untuk secara mandiri terlibat dalam berbagai bentuk kegiatan yang dibutuhkan dalam proses proyek pembangunan tersebut. Oleh karena itu dibutuhkan sebuah tahap dimana masyarakat didorong secara berangsurangsur untuk mengembangkan partisipasinya. Disini jelas bahwa partisipasi masyarakat tidak mungkin berkembang jika hanya mengandalkan keefektifan manajemen birokrasi proyekproyek pembangunan belaka.

Oleh karena itu dibutuhkan suatu alternatif lain yang mampu mengatasi masalah ini. Sebuah alternatif dimana masyarakat sasaran dilibatkan dalam perencanaan proyek-proyek pembangunan. Suatu alternatif dimana komunikasi atau arus informasi timbal balik antara perencana proyek, pengelola dan masyarakat terbentuk sehingga kebencengan (bias) dapat dikurangi dan Partisipasi Kognitif dapat terjadi seperti yang dikemukakan Seegelke \& Schack (2016) sebagai Cognitive Representation 
sebagai dasar dari Model Tindak Manusia. Model Tindak Manusia (Human Action Model) inilah yang diuji cobakan dalam proyek eksperimen sosial oleh PSLH - ITB di Ciamis untuk menemukan sebuah mekanisme yang bisa dikembangkan oleh pemerintah melalui manajemen birokrasi pembangunan guna mengembangkan partisipasi masyarakat.

Model Tindak Manusia ini memanfaatkan secara komprehensif teknik pendidikan, perencanaan partisipastif, pengambilan keputusan interaktif, pengawasan dan evaluasi yang berkesinambungan. Dengan tujuan memperlancar arus informasi antara masyarakat sasaran dengan para perencana dan pelaksana proyek-proyek pembangunan sehingga posisi masyarakat sasaran bisa lebih sentral dalam pengambilan kebijakan proyek. Model ini didasarkan pada beberapa konsep dasar yaitu,

Satu. Masyarakat Merupakan Sebuah Ekosistem. Masyarakat sebagai sebuah ekosistem terdiri dari tiga subsistem yaitu Manusia, Budidaya dan Lingkungan. Dalam konteks ini, perusakan lingkungan misalnya terjadi oleh karena tidak ada keseimbangan antara perkembangan penduduk (manusia), perkembangan pendidikan dan kelembagaan (budidaya) untuk memanfaatkan lahan-lahan pertanian (lingkungan). Dengan demikian, proyekproyek pembangunan yang berbentuk fisik misalnya pembangunan jalan, terassering dan irigasi; namun tidak disertai perubahan sikap (manusia) dan pengembangan kelembagaan (budidaya) justru tidak membantu tumbuhnya proses perubahan yang penting bagi pembangunan.

Keadaan seperti ini, sering membuat ketidakseimbangan ekologis yang lebih mengkhawatir - kan. Demikian juga halnya dengan proyek-proyek pembangunan yang bersifat komprehensif seperti pembangunan waduk, irigasi atau pengembangan pertanian terpadu; seringkali mengandung kelemahan yang mendasar yaitu ketergantungan yang sangat tinggi pada sumber-sumber dana dari luar dan tidak berakar kuat serta melembaga didalam masyarakat. Oleh karena adanya benturan-benturan nilai dan budidaya masyarakat.

Dengan melihat masyarakat sasaran sebagai sebuah ekosistem maka pembangunan dilihat sebuah proses pertumbuhan interdependensi dari kegiatan-kegiatan didalam masyarakat pedesaan, yang didorong oleh kebutuhan dasar masyarakat desa dan keterikatan dalam masyarakat dalam proses pembangunan. Proses pertumbuhan ini dapat dimulai dengan adanya rangsangan ekstern dan dinamika intern akan menentukan kebutuhan sumber daya sebagai jawaban atas dorongan ekstern sehingga ada keterpaduan antara dorongan ekstern dengan persepsi dan harapan masyarakat desa.

Kedua. Penelitian dan Perencanaan Partisipatif. Tujuan dan sasaran-sasaran proyek-proyek pembangunan nasional dalam banyak segi masih belum merupakan kebutuhan masyarakat desa. Oleh karena masyarakat desa sendiri memiliki tujuan dan sasaran yang tumbuh dari kebutuhan dasarnya. Perjumpaan antara tujuan dan sasaran pembangunan nasional dengan tujuan dan sasaran masyarakat desa tidak dapat diartikan secara sepihak dimana proses penetapan tujuan dan sasaran hanya oleh pihak-pihak pelaksana proyek yang berada diluar masyarakat desa.

Perjumpaan itu hendaknya ditempuh dalam sebuah sistem yang berkembang secara dinamis dalam ruang dan waktu dimana perubahan-perubahan tujuan, sasaran maupun prioritas tergantung pada berbagai faktor yang berada dilingkungan, persepsi dan pandangan dari berbagai pihak maupun kelompok yang berbeda. Oleh karena sifatnya yang dinamis maka dibutuhkan sebuah mekanisme untuk menyelesaikan konflik kepentingan dalam berbagai keputusan.

$$
\text { Melibatkan masyarakat dalam }
$$


proses penelitian dan perencanaan partisipatif adalah sebuah upaya untuk menjembatani berbagai pihak yang berkepentingan. Baik antara masyarakat desa dengan pemerintah, masyarakat desa dengan para pemodal swasta manupun antar kelompok didalam masyarakat desa sendiri. Proses pelibatan ini berjalan terus menerus, baik secara formal maupun informal dengan demikian terjadi sebuah dialog yang intensif sekaligus merupakan sebuah proses pendidikan bagi semua pihak.

Melalui proses ini tumbuhlah sebuah jaringan kegiatan, komunikasi dan pada saatnya kelembagaan yang merupakan pola interaksi pembangunan. Sekaligus merupakan infrastruktur yang terbuka bagi peningkatan jangkauan tujuan serta sasaran-sasaran pembangunan.

Ketiga. Fungsi Perantara. Perbedaan kepentingan antara tujuan dan sasaran pemerintah dengan kepentingan masyarakat merupakan sumber konflik yang tidak dapat dihindari. Masyarakat yang cenderung kurang terorganisasi dengan baik sehingga cenderung tidak dapat memanfaatkan proyek tersebut secara optimal. Keadaan ini merupakan potensi konflik yang berbahaya di masa depan. Dalam situasi demikian, Fungsi Perantara sangat dibutuhkan untuk menyelesaikan potensi-potensi konflik tersebut. Sekaligus menjadi penggerak masyarakat untuk memulai proses perubahan sehingga masyarakat jauh lebih siap dalam menghadapi pemerintah dan swasta

Sebagai contoh, dalam proyek Ciamis yang dilakukan oleh PSLH-ITB. Di desa Cigaru dan Sagalaherang untuk menguji sebuah pendekatan alternatif terhadap pengelolaan lingkungan hidup. Kedua desa tersebut terletak di lembah sungai Citanduy. Desa Cigaru adalah sebuah desa subsisten dengan jumlah penduduk $233 \mathrm{KK}$ dengan total luas wilayah 152 Ha dengan rata-rata luas kepemilikan tanah 0.63 Ha. Seluruh bergantung pada usaha pertanian lahan kering dengan tingkat produksi yang sangat rendah dengan hasil produksi hanya 2.1 ton per Ha. Penyebab utama adalah kualitas bibit yang rendah, minim pemupukan, jenis tanah tidak cocok dan laju erosi yang parah.

Pendekatan yang diujicobakan adalah Model Tindak Manusia yang menitikberatkan pada keterlibatan masyarakat dalam pengelolaan lingkungan. Perencanaan didasarkan atas analisis keadaan dan perkembangan masyarakat. Rencana tersebut menjadi bahan bagi para petugas lapangan untuk melakukan dialog dengan kelompok sasaran. Dialog dilakukan dengan latihanlatihan berpikir logis melalui permainan kartu masalah serta alternatif pemecahannya melalui permainan ini rencana proyek masuk kedalam diskusi kelompok. Kegiatan ini kemudian dilanjutkan dengan rembug desa dimana masyarakat telah diap untuk melakukan identifikasi kebutuhan, merumuskan masalah dan cara-cara mengatasinya. Hal ini dilakukan melalui teknik pengambilan keputusan interaktif yang dilakukan dalam bentuk dialog dengan petugas lapangan. Tahap ini cukup menentukan oleh karena ada kemungkinan bahwa masyarakat sasaran didominasi oleh petugas lapangan. Apalagi jika petugas lapangan kurang memiliki sikap sebagai pendidik dan kurang luwes.

Berdasarkan pengalaman PSLH-ITB di Ciamis, guru adalah pemimpin informal yang sangat efektif dalam mendorong transformasi masyarakat. Dengan demikian para guru ini dipersiapkan sebagai Perantara sehingga mampu menjembatani komunikasi dan berperan sebagai fasilitator. Para guru ini ternyata mampu terlibat dalam proses pengambilan keputusan, mulai dari dalam kelompok, desa, kecamatan hingga ke pemerintah pusat. Juga aktif menyebarluaskan informasi atas hasil yang dicapai sehingga dapat diserap oleh masyarakat. 
Mereka juga terlibat dalam penyusunan program dan pengembangan lembaga yang dilakukan secara terpadu. Identifikasi masalah dilakukan dengan cara penelitian bersama yaitu dengan cara kelompok sasaran bersama dengan petugas lapangan meneliti effektivitas membuat terasering; yang dilakukan dengan cara mengamati para pekerja membuat terasering. Hasil pengamatan didiskusikan bersama dalam pertemuan secara evaluatif setelah tiga kali pertemuan akhirnya ditemukan teknik membuat terasering yang paling efektif. Cara yang sama dilakukan untuk proses pemilihan bibit, pemupukan, perawatan tanaman. Semuanya dilakukan dalam sebuah proses pendidikan yang mengembangkan sikap kritis dan antisipatif secara terbuka. Dengan cara ini terjadilah sebuah transformasi yang menyeluruh dalam pengelolaan pertanian di Ciamis.

Keberhasilan proyek ini dapat dilihat pada perubahan sosial yang terjadi di Ciamis yaitu pada cara masyarakat berkomunikasi dan mengambil keputusan, terjadi peningkatan kemampuan dalam menyerap informasi, keterbukaan terhadap perubahan, keberanian bernegosiasi dan meningkatnya sikap kritis terhadap berbagai bentuk tawaran dari luar, keberanian dan keterbukaan untuk mengemukakan pendapat.

Seluruh pengalaman ini merupakan masukan yang sangat berarti bagi pengembangan birokrasi proyek-proyek pembangunan sehingga proyek-proyek tersebut dapat lebih efektif diterima karena masyarakat sasaran terlibat dalam proses sehingga meningkatkan rasa memiliki (sense of belonging) masyarakat yang pada saatnya mendorong transformasi menuju ke sebuah perubahan yang merupakan tujuan yang ingin dicapai melalui proyek tersebut.

\section{KESIMPULAN}

Pertama. Manajemen Birokrasi Tidak Netral. Manajemen birokrasi cenderung berpihak kepada perencana dan pelaksana proyek pembangunan; dengan demikian, birokrasi kurang peka terhadap tumbuh dan berkembangnya prakarsa masyarakat. Dalam konteks ini upaya pemerintah mengembangkan prakarsa masyarakat melalui proyek-proyek pembangunan mengalami hambatan yang serius.

Hambatan birokrasi semacam ini seringkali hanya diartikan sebagai ketidak mampuan pengelola. Konsep semacam ini muncul karena asumsi bahwa birokrasi itu sebuah alat yang efisien dan efektif terlepas dari pengelolanya. Namun asumsi tersebut kurang tepat karena akar masalahnya terletak didalam birokrasi itu sendiri yaitu pada ketergantungan pada sumber-sumber dana pada pihak luar dan diikuti dengan ketatnya pengawasan yang cenderung diartikan secara kuantitatif. Semua ini hanya memperlemah kemampuan para perencana dan pelaksana birokrasi dalam merespons perkembangan prakarsa masyarakat.

Kedua. Kesiapan Masyarakat adalah Signifikan Bagi Pencapaian Tujuan Proyek. Kondisi masyarakat yang kurang terorganisasi sehingga kurang siap untuk menerima proyek dan menuju ke perubahan. Dengan demikian hadirnya proyek-proyek pembangunan sering kali justru menciptakan ketegangan tersendiri bagi masyarakat, yang pada saatnya bisa menciptakan berbagai gesekan yang menuju ke konflik. Akibatnya proyek pembangunan itu sendiri tidak akan dinikmati masyarakat atau bahkan dianggap sebagai ancaman bagi masyarakat. Jika ini yang terjadi tujuan proyek pembangunan itu sendiri tidak akan tercapai.

Ketiga. Memperlancar Arus Informasi. Percobaan PSLH-ITB dengan menerapkan Model Tindak Manusia bertujuan memperlancar arus informasi antara masyarakat dengan swasta diluar desa, antara masyarakat dengan para perencana dan pengelola proyek dan antar kelompok didalam masyarakat itu sendiri.

Melalui Model ini dikembangkan 
juga pelatihan-pelatihan meneliti, merumuskan masalah, memilih alternatif, pemecahan masalah, pengembangan kelembagaan. Seluruh upaya ini bertujuan mencapai sebuah transformasi masyarakat yang menyeluruh dan mereka berhasil dengan penerapan Model tersebut serta dapat melakukan transformasi masyarakat secara menyeluruh.

Atas dasar itu perlu dipertimbangkan untuk penggunaan model ini dalam menerapkan proyek- proyek pembangunan sehingga proyek-proyek tersebut dapat menciptakan transformasi dalam kehidupan masyarakat.

\section{REFERENSI}

Aron, R. 1994. The Stages of Sociological Thinking. Lisboa: Publicações Dom Quixote

Adriano, Fermin. 1984. 'A Critique of the Bureaucratic Authoritarian State Thesis: The Case of the Philippines' Journal of Contemporary Asia, vol.14, no. 4, hal. 459-84.

Alavi, Hamza.1979.'The State in Post Colonial Societies: Pakistan and Bangladesh.'in Goulbourne. ed. Atal, Yogash \& Pieris, Ralph. 1980. Bunga Rampai: Kritik Asia terhadap Pembangunan. Alih bahasa

Hasan Basari. Jakarta: Yayasan Ilmu-Ilmu Sosial.

Becker, David G. 1984.'Development, Democracy and Dependency in Latin America: A Post Imperialist View.' Third World Quaterly, vol.6, no.2, hal. 411-31.

Berger, Peter. 1982. Piramida Kurban Manusia. Jakarta: LP3ES

Brautigam, Deborah. 1991. Governance and Economy: A Review. World Bank Policy Research Working Papers No. 815. Washington: The World Bank.

Breman, J. 1980. 'The Village on Java and the Early Colonial State.'Contemporary Asian Studies Publications No.1. Rotterdam.
Bron, Agniezka \& Schemann, Michael. eds. 2001. Civil Society, Citizenship and Learning. Bochum: the Ruhr University Bochum

Budiman, Arief. 1982. 'Bentuk Negara dan Pemerataan Hasil-Hasil Pembangunan.' Prisma, No. 7, Th. XI

--------. 1987. 'Kebudayaan Kekuasaan atau Sosiologi Kekuasaan?’ Prisma, No. 3, Th. XIV.

\& Rietveld, Piet. 1986.'Indonesia Menuju Lepas Landas Masih Berapa Jauh?'Prisma, No.1, Th. XV.

------- \& Van Ufford, Phillip Quarles. eds. 1988. Krisis Tersembunyi Dalam Pembangunan: Birokrasi- Birokrasi Dalam Pembangunan. Jakarta: Gramedia.

Chakrit Noranitipadungkarn. 1981. Elites, Power Structure and Politics in Thai Communities. Bangkok: National Institute of Development Administration.

Chambers, Robert. 1983. Rural Development: Putting the Last First. London: Longman Chandoke, Neera. 1995. State and Civil Society. New Delhi: Sage Publications.

Chirac, J. 1996. The Economy Must Be Made to Serve People. Makalah disampaikan di Konferensi Buruh International.

Clegg, S. 1990. Modern Organizations: Organization Studies in the PostModern World. London: Sage Collier, David. Ed. 1979. The New Authoritarianism in Latin America. Princeton: Princeton University Press.

Cotton, James. 1989. 'From Authoritarianism to Democracy in South Korea.' Political Studies, Vol. 37, no. 2, hal. $244-259$.

Donati. A \& Rossi, C. eds. 2004. Brownfield Sites II: Assesment, Rehabilitation and Development. Italy: University of Siena. 
Effendi, Sofian. 1989. Kebijaksanaan Publik Berwawasan Pemerataan. Makalah. Yogyakarta: Fisipol UGM

Erath, William \& Kruijt, Dirk. 1988. 'Badan Kerjasama Pembangunan Negeri Belanda: Kebijaksanaan Organisasi dan Pelaksanaan.' Budiman \& Van Ufford. eds. hal. 55 -78 .

Evans, Peter. 1979. Dependent Development: The Alliance of Multinational, State and Local Capital in Brazil. Princeton: Princeton University Press.

-, Skocpol, Theda \& Rueschemeyer, Dietrich. (eds.). 1985. Bringing the State Back In. Cambridge: Cambridge University Press.

Evers, Hans-Dieter. ed. 1973. Modernisation in South-East Asia. Singapore: Oxford University Press.

--------. 1973.' Group Conflict and Class Formation in South-East Asia.' in Evers, ed.

-- \& Schiel, Tilman. 1990. KelompokKelompok Strategis: Studi Perbandingan tentang Negara,

Birokrasi dan Pembentukan Kelas di Dunia Ketiga. Alih bahasa Aan Effendi. Jakarta: Yayasan Obor Indonesia.

Feith, Herbert. 1980. 'Repressive Developmentalist Regimes in Asia: Old Strength, New Vulnerabilities.' Prisma, No.19, Hal. 39 - 55.

Giddens, A. 1997. Sociology. Lisboa: Fundação Calouste Gulbenkian.

Goulbourne, Harry. (ed.). 1979. Politics and the State in the Third World. London: Macmillan Hadad, Ismid. 1980. 'Persoalan dan Perkembangan Pemikiran Dalam Teori Pembangunan.' Prisma, No. 1, Th. IX.

--------. 1983. 'Menampilkan Potret Pembangunan Berwajah Swadaya Masyarakat.' Prisma, No. 4, Th. XII.

Hendrata, Lukas. 1983. 'Birokrasi, Partisipasi dan Pemerataan Hasil Pembangunan.' Prisma, No. 4, Th, XII.
Hettne, Bjorn. 1986. Ironi Pembangunan di Negara Sedang Berkembang. Jakarta: Sinar Harapan Hewison, Kevin.et.al.(eds). 1993. Southeast Asia in the 1990s: Authoritarianism, Democracy \& Capitalism. St.Leonards: Allen \& Unwin Pty Ltd. Hyden, Goran. 2008. Power \& Politics in Africa: Institution, Power and Policy Outcomes in Africa. Discussion Paper, No. 2, June. London: Overseas Development Institute.

Huntington, Samuel. 1984. 'Will More Countries Become Democratic?' Political Science Quarterly, Vol. 99, No. 2, hal. 193 - 218.

-1987. 'The Goals of
Development.' in Weiner \&
Huntington.eds.

Hutapea, Richard \& Suwondo, Kutut. 1990. Beberapa Catatan tentang Organisasi-Organisasi

Pembangunan di Pedesaan. Makalah Tidak Dipublikasikan. Salatiga: PPSUKSW.

Karnawati, Enny. 2014. Partisipasi Masyarakat Dalam Pembangunan. Makalah Tidak Dipublikasikan: Semarang: Badan Kepegawaian. Pendidikan \& Pelatihan Kota Semarang.

Korten, David C \& Alfonso, Felipe B (eds.). 1981. Bureaucracy and the Poor: Closing the Gap. Singapore: McGraw-Hill International Book Company.

Kusumowidagdo. 1983. 'Pembangunan Politik Orde Baru Menghadapi Krisis Partisipasi.' Prisma, No. 1, Th. XII.

Lane, T, et.al. 1999. IMF Supported Programs in Indonesia, Korea and Thailand: A Preliminary Assesment. Working Paper No. 178, International Monetary Fund. Washington: IMF, January.

Lavergne, Real P. 1988.'Pengelolaan Bantuan Asing Kanada: Struktur, Sasaran dan Keterbatasan.' di Budiman \& Van Ufford. eds. hal. 119 -145 . 
Liddle, William. 1989. Merekayasa (mereka-reka) Demokrasi di Indonesia. Jakarta: Kompas

Mintzberg, Henry. 1970. 'Structured Observation as A Method to Study Managerial Work.' Journal of Management Studies, Vol. 7, Issue 1, February, hal. 87 - 104.

Myrdal, Gunnar. 1968. Asian Drama: An Inquiry into the Poverty of Nations. Pantheon O’Donnell, Guillermo. 1979. 'Tension in the Bureaucratic Authoritarian State and the Question ofDemocracy.' In David Collier.ed. -. \& Schmitter, Philippe (eds.). 1986. Transition for Authoritarian Rule: Tentative Conclusion about Uncertain Democracies. Baltimore: The John Hopkins University Press.

Offenbacker, B.S. 2004. 'Overcoming Barriers to Effective Public Participation.' In Donati, et.al. eds. Parera, Frans M \& Koekerits, $T$ Jacob. eds. 1999. Masyarakat Versus Negara: Paradigma Baru Membatasi Dominasi Negara. Jakarta: Kompas

Petras, James. 1989. 'State, Regime and the Democratization Muddle.' Journal of Contemporary Asia, Vol. 19, No. 1, hal. $26-32$.

Poerbo, Hasan. 1982. Pengembangan Sistem Pengelolaan Sumber Daya Lokal: Studi Kasus Hulu Sungai Citanduy, Kabupaten Ciamis. Makalah Tidak Dipublikasikan. Bandung: PSLH - ITB.

\& Nordholt, Nico S. 1983. 'Suara dari Lapangan. Memperkenalkan Model Tindak Manusia.' Prisma, No. 6, Th. XII. 

JRMB, Volume 16, No. 1, Juni 2021 

PROBLEMA MANAJEMEN BIROKRASI PROYEK

PEMBANGUNAN

..(Widihandojo) 